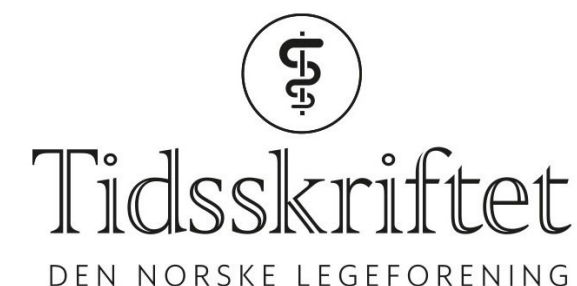

DEN NORSKE LEGEFORENING

\title{
De frafalne
}

LEGELIVET

\section{CECILIE NORMANN BIRKELI}

E-post: cecilie.normann@legeforeningen.no LEFO - Legeforskningsinstituttet

Vi vet lite om leger som faller fra underveis i spesialiseringsløpet. Bør dette fokuseres mer på?

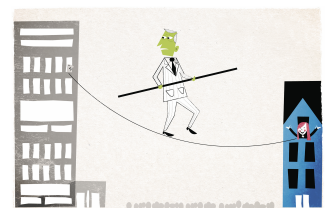

Illustrasjon: Ikon Images / NTB

Scanpix

Det har tidligere vært forsket på preferanser for karrierevalg blant leger og prestisjen de medisinske spesialiteter har i norsk sammenheng $(1,2)$. Men hva vet vi om frafall blant leger underveis i spesialiseringsløpet og deres videre karriereplaner?

Selv om det er grunn til å anta at andelen leger i spesialisering har $ø$ kt betraktelig de siste ti årene, har vi ingen data som viser hvorvidt de slutter, skifter spesialitet eller endrer karriereplaner underveis i spesialiseringsløpet (Anders Taraldset, Legeforeningen, personlig meddelelse).

Internasjonalt er det få studier som samlet tar for seg frafall blant leger underveis i spesialiseringsløpet, til tross for at frafall kan ha høye samfunnsmessige kostnader og påvirke stabiliteten i spesialiseringsløpet (3). Eksisterende studier har enten vært rettet mot enkeltspesialiteter eller man har tatt for seg årsaksforklaringer der data ikke nødvendigvis har blitt samlet inn fra legene selv.

I Nederland fulgte en gruppe forskere leger i sykehusspesialisering over en periode på to år for å finne ut hvilke faktorer som hadde betydning for frafall underveis $\mathrm{i}$ spesialiseringsløpet, og deres videre karriereplaner (3). Frafallsraten i sykeshusspesialitetene alt i alt var $11 \%$ i perioden $2010-15$, men dette varierte fra $2,2 \%$ (plastikkirurgi) til 24,3\% (nukleærmedisin). Funnene i denne studien viste at de hyppigst rapporterte faktorene som bidro til frafall, var jobb-hjem-balanse, arbeidsoppgaver (innhold), arbeidsmengde og spesialitetskultur.

Det å ha et system som fanger opp frafall underveis i spesialiseringsløpet, er viktig for å sikre god utdanning, stabilitet og forutsigbarhet

De fleste som sluttet eller endret spesialitet, gjorde det i løpet av spesialiseringens andre 
eller tredje år (50\%). Samtidig fant man at andelen som forlot spesialiseringsløpet sent (etter 4-6 år), var høy (25\%). For å forhindre frafall foreslo forfatterne å styrke den individuelle veiledningen underveis i spesialiseringsløpet, både med tanke på å gi spesialistkandidatene et mer realistisk bilde av hva slags krav de kan vente seg på jobb, om de passer til faget og fokus på jobb-hjem-balanse.

Et spesielt interessant funn i denne studien er at flesteparten av de som skiftet spesialitet $(64,8 \%)$, valgte ikke-sykehusspesialiteter som videre karrierevei. Dersom studien hadde inkludert spesialiteter utenfor sykehus, ville det vært interessant å se om mønsteret der gikk i motsatt retning. Det ville også vært interessant å vite om spesialiteten legene forlot, var den de primært hadde ønsket seg.

Med den nye spesialitetsstrukturen som ble innført i 2017 i Norge, er det viktig å sikre god gjennomstrømning i de ulike spesialitetene. Det å ha et system som fanger opp frafall underveis i spesialiseringsløpet, er viktig for å sikre god utdanning, stabilitet og forutsigbarhet med tanke på antall spesialister i ulike fag.

\section{LITTERATUR:}

1. Wiers-Jenssen J, Aasland OG. Endring i medisinstudenters karrierepreferanser under første del av studiet. Tidsskr Nor Lægeforen 1999; 119: 2858-64. [PubMed]

2. Album D, Westin S. Do diseases have a prestige hierarchy? A survey among physicians and medical students. Soc Sci Med 2008; 66: 182-8. [PubMed][CrossRef]

3. Bustraan J, Dijkhuizen K, Velthuis S et al. Why do trainees leave hospital-based specialty training? A nationwide survey study investigating factors involved in attrition and subsequent career choices in the Netherlands. BMJ Open 2019; 9: eo28631. [PubMed][CrossRef]

Publisert: 11. mars 2020. Tidsskr Nor Legeforen. DOI: 10.4045/tidsskr.20.0094

(C) Tidsskrift for Den norske legeforening 2020. Lastet ned fra tidsskriftet.no 